\title{
Obesity among children aged $10-13$ years in public and private elementary schools
}

\author{
Evi Kamelia, MD; Nurdiani, MD; Tiansa Sembiring, MD; Hakimi, MD; Iskandar Z Lubis, MD
}

\begin{abstract}
Background In the last few years, the prevalence of obesity among Indonesian children has been beginning to increase slowly, but studies and publications about obesity are limited. In accordance with the improvement of social economic and child health, obesity can be seen more frequently as a problem in children.

Objective To evaluate and compare the prevalence and related factors of obesity among children 10-13 year-old who were students of two kinds of school, namely public and private elementary school.

Methods A cross sectional study was done from October until December 1995 on 276 elementary school students aged 10-13 years consisting of 138 public and 138 private elementary school students. Data were collected by a questionnaire including anamnesis of family history and type of daily diet, physical examination, and anthropometric measurement.

Results The prevalence of obesity among children in the public and private elementary schools was $9 \%$ and $20 \%$ respectively, which showed a significant difference $(p<0.01)$. The prevalence of obesity among children was significantly related to parents' welfare, excessive daily calorie intake, level of physical activity, and obesity problem in the family.

Conclusion The prevalence of obesity in students of private and public elementary schools was $20 \%$ and $9 \%$ respectively. Social economic level, calorie intake, sport activities, and obesity problems in the family are factors related to the prevalence of child obesity [Paediatr Indones 2003;43:38-41].
\end{abstract}

Keywords: obesity, prevalence, public school, private school

I $\mathrm{n}$ the last few years, an increase of the prevalence of overweight children has been reported, especially in the cities. However, our society's knowledge about obesity is very poor indeed. This problem occurs more frequently in the new improvement of social lifestyle and the development of economy and it is more likely to become a nutritional problem in the society. ${ }^{1}$ The prevalence of obesity among Indonesian children can not be established yet. A study on teenagers aged 12-18 years in 1988 showed an increase of obesity prevalence from $6.2 \%$ at the age of $12-13$ years to $11.4 \%$ at the age of $17-18$ years. The prevalence of obesity among female teenagers was higher than males $(10.2 \%$ vs. $3.2 \%) .{ }^{1}$ Obesity can be caused by continuing interaction of multifactor, such as excessive energy intake, low energy expenditure, psychological disorders, genetic problems, and other diseases. ${ }^{2,3}$ Complications of obesity that have been found are psychological disorders, respiratory complication, and orthopedic problems. Moreover, if the problem continues until adulthood it can be a risk for getting degenerative metabolic disease, hyperlipoproteinemia, hypercholesterolemia, diabetes mellitus, hypertension, and cardiovascular disease, thus increasing the mortality rate..$^{1-10}$

Students from school with high fees and complete equipments usually come from families with good economic status, and therefore are more prone to develop obesity. A decrease of the level of obesity re-

From the Department of Child Health, Medical School University of North Sumatera/Adam Malik General Hospital, Medan.

Reprint requests to: Evi kamelia, MD. Department of Child Health, Medical School, University of North Sumatera, Adam Malik Hospital, Medan, Indonesia. Tel./Fax. 62-21-836 1721.

Presented at the $10^{\text {th }}$ Congress of the Indonesian Pediatricians Society, Bukit Tinggi, June 22 - 25, 1996. 
lates directly with decreased prevalence of obesity. ${ }^{9}$ That is why a study is needed to know what factors and how they are related to obesity. The aim of this study was to assess the prevalence of obesity in children aged 10-13 years in two kinds of elementary school (public and private).

\section{Methods}

A cross sectional study was done on 276 children (138 from private and 138 from public elementary schools) from October 1995 until December 1995. They were $10-13$ year-old from the $5^{\text {th }}$ and $6^{\text {th }}$ grade who were clinically healthy.

Data were collected by means of questionnaire, physical examination, and anthropometrical measurement. The questionnaire consisted of identity of the children and their parents, child's daily diet, and extracurricular activities in the last week. Classification of the nutritional status was based on criteria recommended by Semiloka Antropometri 1991. Based on the classification of WHO-1990, parents with income of more than Rp 65,000/capita/months or $\$ 370$ /capita/year was defined as having good socioeconomic status. ${ }^{11}$

According to the Recommended Dietary Allowances for Indonesian in 1988, the mean daily calorie intake is $1950 \mathrm{kcal}$ for male and $1750 \mathrm{kcal}$ for female. Daily calorie intake of more than what is recommended was stated as over nutrition. In relation to nutritional status of the parents, obesity was stated if either father or mother was reported as obese. Body weight was measured using Beam balance Detectomedic with accuracy up to $0.1 \mathrm{~kg}$, while height was assessed by a microtoise with accuracy up to $0.1 \mathrm{~cm}$.

Data were compiled in distribution tables and cross tables. The correlation between qualitative variables was assessed using Chi Square Test and considered as significant if $\mathrm{p}<0.05$.

\section{Results}

The characteristics of 276 elementary school children are illustrated in Table 1 . There was a significant difference in the prevalence of obesity between students of public elementary school (9\%) and students of private elementary school (20\%) $(\mathrm{p}<0.01)$.

Among 39 obese children, 36 had good socioeconomic status and 3 had low socioeconomic status. There was a significant difference $\left(x^{2}=\right.$ $\mathrm{p}<0.01)$.

Out of total of 46 students with over intake of

Table 1. Characteristics of the subjects

\begin{tabular}{lllll}
\hline Variable & Public ES & \multicolumn{3}{l}{ Private ES } \\
\hline Population & 138 & & 138 & \\
Age (month) \pm SD & $137 \pm 7.2$ & & $133 \pm 7.8$ & \\
Gender : & $\mathrm{n}$ & $\%$ & $\mathrm{n}$ & $\%$ \\
$\quad$ Male & 65 & 47 & 68 & 48 \\
$\quad$ Female & 73 & 53 & 70 & 51 \\
Anthropometric & & & & \\
Body weight (kg) \pm SD & $34.7 \pm 6,6$ & & $37.9 \pm 7.1$ & \\
Body length (cm) \pm SD & $123.9 \pm 6.9$ & & $138.2 \pm 7.7$ & \\
Energy intake/day (kcal) : & & & & \\
$\quad$ & $1850 \pm 23$ & & $1970 \pm 46$ & \\
$\quad$ Male & $1670 \pm 34$ & & $1850 \pm 39$ & \\
$\quad$ Female & $\mathrm{n}$ & $\%$ & $\mathrm{n}$ & $\%$ \\
$\quad 12$ & 9 & 27 & 20 \\
$\quad$ Obesitity & 14 & 10 & 33 & 24 \\
$\quad$ Overweight & 33 & 24 & 41 & 30 \\
$\quad$ Good & 59 & 43 & 34 & 25 \\
$\quad$ Moderate & 20 & 14 & 3 & 1 \\
$\quad$ Low & 0 & 0 & 0 & 0 \\
$\quad$ Bad & $\mathrm{n}$ & $\%$ & $\mathrm{n}$ & $\%$ \\
Social economic & 28 & 20 & 138 & 100 \\
$\quad$ Good & 110 & 80 & 0 & 0 \\
$\quad$ Low & & & & \\
\hline
\end{tabular}


energy, 35 (76\%) had obesity, while among 230 students with normal intake, only 4 (2\%) suffered from obesity. There was a significant difference $\mathrm{p}<0.01$.

Among students suffering from obesity, the proportions of those with mild, moderate, and high sport activity were $28 \%, 5 \%$, and $18 \%$ respectively, while among the non obese students, they were $72 \%, 95 \%$, and $82 \%$ respectively. The difference was statistically significant.

Among 29 students with history of parental obesity, there were 10 who suffered from obesity, while of 247 students without history of parental obesity, only $20(8 \%)$ suffered from obesity. The difference was statistically significant.

\section{Discussion}

The prevalence of obesity in children from private elementary schools was different from that of public elementary schools, which was related with the level of economic status and calorie intake.

According to Wiramihardja (1992), high economic level can automatically increase the purchasing power especially for food, but without the appropriate nutritional knowledge it can cause nutritional problems such as obesity. ${ }^{13}$

In this study, the quality and intensity of sport activity was not evaluated. We only evaluated the quantity of sport activity. It was found that most of them did light sport activity.

In this study, we found significant association between the prevalence of child obesity and the history of parental obesity. It was found that if both parents had an overweight problem, the prevalence of obesity in the children increased by two folds compared to that when only one of the parents had obesity problem. It may be due to the habit of eating or genetic factor. ${ }^{2}$

Emotional disorder is one of the main causes of child obesity. Children with psychological problem usually isolate themselves from their environment that can initiate the sense of excessive hunger, as a compensation of their problems, which furthermore can cause obesity. Unfortunately, in this present study, we did not evaluate psychological factors.

Activity has been proven to be a major factor in energy balance. Other studies had shown that physical activity may influence food intake. Food intake and body weight tend to be higher in persons with sedentary life style than in those with moderate degree of activity. Such studies suggested that activity could be a significant factor in the etiology of obesity in some children and adolescents. ${ }^{9}$ In this present study, we also found a significant association between either calorie intake or sport activities and the occurrence of obesity.

As a conclusion, the prevalence of obesity in the private and public elementary school students was 20\% and 9\%, respectively. Social economic level, calorie intake, sport activities, and obesity problems in the family are factors related to the prevalence of childhood obesity. Further study using more variables is needed.

\section{References}

1. Samsudin. Gizi lebih pada anak dan masalahnya. Risalah Widyakarya Pangan dan Gizi V LIPI; 1993 April 20-22; Jakarta: LIPI; 1994. p. 396-408.

2. Aritaki S. Obesity in children, Asean Med J 1993; 36:111-7.

3. Samsudin. Obesitas pada anak, penanggulangan dan pencegahannya. In: Suyitno H, Setiadi TE, Soeroso S, Koesen R, Deliana E, editors. Proceedings of the $9^{\text {th }}$ National Congress of Pediatric;1993 June 16-19; Semarang, Indonesia. p. 93 - 113.

4. Nasar SS. Obesitas pada anak: aspek klinis dan pencegahan. In : Samsudin, Nasar SS, Syarif DR, editors. Masalah gizi ganda dan tumbuh kembang anak. Naskah lengkap pendidikan kedokteran berkelanjutan ilmu kesehatan anak FKUI XXXV; 1995 Aug 11. 12;Jakarta: Bina Aksara; 1995. p. 69-81.

5. Thaman OP. Obesity. In: Textbook of pediatrics. New Delhi: Mc Graw-Hill Publishing Company Limited; 1984. p. 710-2.

6. Dietz WH. Prevention of childhood obesity. In: Christopherson ER, Hinney JW, Friman PC, editors. The pediatric clinics of North America;1986; 331:823-33.

7. Dietz WH. Childhood and adolescent obesity. In: Walker WA, Wakkins JB, editors. Nutrition in pediatrics. Basic science and clinical application. Toronto: Little Brown;1985. p. 769-80.

8. Ontoseno T. Keterlibatan kardiovaskular pada anak dengan obesitas. In: Darius B, Sayoeti Y, Pabuti A, Alkamar A, editors. Proceedings of the $10^{\text {th }}$ National 
Evi Kamelia et al: Obesity among children in public and private elementary schools

Congress of Pediatric; 1996 June 16-29; Bukit Tinggi, Indonesia. Bukit Tinggi: Penerbit Pancaran Ilmu; 1996. p. 319-27.

9. Waldbaum R. Childhood Obesity: an overview. In: Lifshitz F, editor. Pediatric nutrition. New York: Marcel Dekker Inc; 1082. p. 273-95.

10. Kneebone G. Obesity in children. J Pediatric Obstet Gynecol 1990;33-5.
11. World Bank. World development report 1990. Poverty London: Oxford University Press; 1990. Cited from: Wiramihardja K. Kondisi gizi anak sekolah dasar umur 10-13 tahun di Kotamadya Bandung tahun 1992. MKB 1993;25:24-8.

12. Wiramihardja K. Kondisi gizi anak sekolah dasar umur 10-13 tahun di Kotamadya Bandung tahun 1992. MKB 1993;25:24-8. 